\title{
General Overview of Disability and Health Behaviors of Disabled Children
}

\section{Engelliliğe Genel Bakış ve Engelli Çocukların Sağlık Davranışları}

\author{
Tülin Çoban ${ }^{1}{ }^{*}$ Hilal Özcebe ${ }^{2}$
}

\begin{abstract}
World Health Organization (WHO) defines disability as "an umbrella term that involves impairments in body function or structure, the difficulties encountered in performing an action, and the restriction of participation in life requirements". While $5 \%$ of children under the age of 15 years have a moderate or severe disability worldwide, $21.1 \%$ of the disabled individuals are under 15 years old in our country. Disabled individuals face serious obstacles in reaching many services such as medical care, employment, education, transportation and housing. Although there are various legal arrangements in the world and in our country to determine and secure the rights of disabled people, permanent solutions have not been obtained. Disabled individuals subject to discrimination and exclusion, particularly in terms of school and work life, access to economic resources and public services. The physical environment conditions, which are not designed according to the disabilities increase the exclusion from the society. So children with disabilities are one of the most vulnerable groups. Disadvantageous conditions come into the foreground for disabled children in almost all health problems. Disabled children's health may be improved and socialized through a comprehensive approach including the education of the child and the families, providing health and care services. The necessary interventions to maintain and improve the health of the disabled children should be adopted and implemented by all sectors in order to socialize them.
\end{abstract}

Key words: Disability, disabled children, health behaviors

\section{ÖZET}

Dünya Sağlık Örgütü (DSÖ) engeli, “vücut fonksiyonu veya yapısındaki bozuklukları, bireyin bir eylemi yerine getirmesinde karşılaşılan zorlukları ve yaşam gerekliliklerine katılımın kısıtlanmasını kapsayan şemsiye bir kavram" olarak tanımlamaktadır. Dünyada 15 yaş altı çocukların \%5'i yani yaklaşık 93 milyon çocuk orta veya ağır bir engele sahiptir. Ülkemizde ise engelli bireylerin \%21,1'i 15 yaşından küçüktür. Engelli bireyler tıbbi bakım, istihdam, eğitim, ulaşım ve barınma gibi pek çok hizmete ulaşmada ciddi engellerle karşılaşmaktadır. Engellilerin haklarını belirlemek ve güvence altına almak için dünyada ve ülkemizde çeşitli yasal düzenlemeler mevcut olmasına rağmen konuyla ilgili kalıcı çözümlerin uygulanmasında pek çok güçlükle karşıllaşılmaktadır. Engelliler özellikle okul ve iş hayatı, ekonomik kaynaklara ve kamusal hizmetlere erişim konularında ayrımcılık ve dışlanmaya maruz kalmaktadır. Engellilerin engellerine göre tasarlanmamış olan fiziksel çevre koşulları da toplumdan dışlanma durumlarının artmasına neden olmaktadır. Bu sebeplerle, engelli çocuklar incinebilirliği en yüksek gruplardan birini oluşturmaktadır. Sağlık sorunlarının hemen tamamında engelli çocuklara yönelik dezavantajlı durumlar öne çıkmaktadır. Engelli çocukların sağlığının geliştirilmesi ve topluma kazandırılması çocuğun eğitimi, ailelerin eğitimi ve engelli çocuğa sağlık ve bakım hizmetlerinin bir bütün şeklinde verilmesiyle mümkündür. Engelli çocukların yaşama katılabilmeleri için sağlığının korunması ve geliştirilmesine yönelik yapılması gereken müdahaleler tüm sektörler tarafından benimsenmeli ve uygulanmalıdır.

Anahtar kelimeler: Engellilik, engelli çocuklar, sağlık davranıșları

Received Date:27.03.2019, Accepted Date: 31.07.2019

*1 Hacettepe Üniversitesi, Tıp Fakültesi, Dahili Tıp Bilimleri Bölümü, Halk Sağlı̆̆ Anabilim Dalı

*Address for Correspondence / Yazışma Adresi: Tülin Çoban, Hacettepe Üniversitesi, Tıp Fakültesi, Dahili Tıp Bilimleri Bölümü, Halk Sağlığı Anabilim Dalı, E-mail: tulincoban87@hotmail.com

Çoban T., Özcebe H. Engelliliğe Genel Bakıș ve Engelli Çocukların Sağlık Davranışları.TJFMPC, 2019;13 (4): $553-566$.

DOI: $10.21763 /$ tjfmpc.545343 


\section{GİRIŞ}

Dünya Sağlık Örgütü (DSÖ) engeli, “vücut fonksiyonu veya yapısındaki bozuklukları, bireyin bir eylemi yerine getirmesinde karşılaşılan zorlukları ve yaşam gerekliliklerine katılımın kısıtlanmasını kapsayan şemsiye bir kavram” olarak tanımlamaktadır. Engellilik, sadece bir sağlık sorunu değil, bireyin yaşadığı toplumun kendisine bakış açısını etkileyen ve sosyal sorunlarla yüz yüze kalmasına yol açan bir olgudur. ${ }^{1}$

DSÖ’nün verilerine göre dünya nüfusunun yaklaşı \% $\% 15$ 'i engelli bireylerden oluşmakta, bu da yaklaşık 1 milyar engelli anlamına gelmektedir. Dünyada 15 yaş altı çocukların ise \%5'i yani yaklaşık 93 milyon çocuk orta veya ağır bir engele sahiptir. Engelli bireyler tıbbi bakım, istihdam, eğitim, ulaşım ve barınma gibi pek çok hizmete ulaşmada ciddi engellerle karşılaşmaktadır. ${ }^{2} \mathrm{Bu}$ nedenle engelli bireyler, toplumdaki dezavantajlı gruplardan birini oluşturmakta ve sunulan hizmetler ülkenin gelişmişlik göstergesi olarak kabul edilmektedir. Birleşmiş Milletler Kalkınma Programı (United Nations Development ProgramUNDP) verilerine göre engelli bireylerin yaklaşık \%80'i gelişmekte olan ülkelerde yaşamaktadır. ${ }^{3}$

Türkiye Özürlüler Araştırması (2002)'na göre Türkiye'de engelliler, nüfusun \%12,29'unu oluşturmakta olup 2010 yılında yürütülen Özürlülerin Sorun ve Beklentileri Araştırması ise engellilerin \%21,1'inin 15 yaşından küçük çocuklar olduğunu ortaya koymuştur., ${ }^{4,5}$

Kişinin sosyal yaşama aktif olarak katılması için kurumsal ve yasal olarak gerekli tüm önlemler alınsa bile, engellilere yönelik toplumsal alg1 nedeniyle engelli bireyler ekonomik, sosyal ve kültürel yaşamdan dışlanmaktadır. ${ }^{6}$ Avrupa Birliği
(AB)'nde engellilerin \%29,9'u yoksulluk/sosyal dışlanmışlık riski altında iken, Türkiye'de bu sıklık \%77,1' dir. $^{7}$ Engelli çocukların toplumda en fazla dışlanan ve ayrımcılığa en fazla maruz kalan gruplardan biri olduğunu söylemek mümkündür. Okula devamlılıkları düşük ve sağlık hizmetlerine erişimleri zor olan engelli çocukların aynı zamanda toplumda seslerini duyurmaları zor ve her türlü istismara maruz kalma olasılıkları daha yüksektir. ${ }^{8}$ Örneğin, Hindistan'da ilköğretimi tamamlama sıklıkları herhangi bir engeli olmayan çocuklarda \%60'larda iken engelli çocuklarda \%10 civarındadır. $^{9}$

Engelli bireylerin topluma dâhil olamaması, sadece engelli bireyi etkilemekle kalmamakta, toplumun ilerlemesinin de önüne geçebilmektedir. Toplumlarda refah ve barışın sağlanması her bireyin topluma sağlıklı bir şekilde katk1 vermesiyle ve toplumun geleceğini şekillendirecek olan çocukların olabilecek en iyi sağlık düzeyine sahip olmasıyla mümkündür. Öte yandan toplumların engelli bireylere bu konuda destek olma ve gerekli ortamı sağlamaları, gereklilik olmanın yanı sıra bir sorumluluktur. Bunu gerçekleştirmek için "toplumdaki en büyük azınlık" olarak tanımlanan engellilerin haklarını belirlemek ve güvence altına almak için dünyada ve ülkemizde çeşitli yasal düzenlemeler mevcuttur. ${ }^{1}$

\section{Engelli Çocukların Haklarına İlişkin Yasal Düzenlemeler}

Engellilerin Haklarına İlişkin Sözleşme'ye göre, “engelli”, “diğer bireylerle eşit koşullar altında topluma tam ve etkin bir şekilde katılımlarının önünde engel teşkil eden uzun süreli fiziksel, zihinsel, düşünsel ya da algısal bozukluğu bulunan kişiler" olarak tanımlanmaktadır. ${ }^{11} \mathrm{Bu}$ sözleşme, Birleşmiş Milletler (BM) Genel Kurulu'nun 13 
Aralık 2006 tarihli kararıyla kabul edilmiş ve 3 Mayıs 2008 tarihinde yürürlüğe girmiştir. Türkiye Cumhuriyeti, sSözleşmeyi 30 Mart 2007 tarihinde imzalamıştır; Sözleşme 14 Temmuz 2009 tarihli Resmî Gazete'de yayımlanarak 28 Ekim 2009'da yürürlüğe girmiştir. ${ }^{12}$ Sözleşme, engelli çocukların tüm insan haklarından ve temel özgürlüklerden tam olarak yararlanmasının gereği konusunda Çocuk Haklarına Dair Sözleşme'ye taraf devletlere konuyla ilgili üstlendikleri yükümlülükleri hatırlatmaktadır. Genel ilke olarak engelli çocukların kendi kimliklerini koruyabilme haklarına saygı duyulmasını benimseyen sözleşmenin, engelli çocuklarla ilişkili olan 7 . maddesi taraf devletlere "tüm eylemlerde, çocuğun yüksek yararının gözetilerek, engeline ve yaşına uygun şekilde ve diğer çocuklarla eşit olarak tüm temel hak ve özgürlüklerden yararlanmasının sağlanması" görevini yüklemekte ve görüşlerini serbestçe ifade etme hakkına özel olarak vurgu yapmaktadır. ${ }^{11}$ Taraf devletler, sSözleșmenin denetim organı olan Engelli Hakları Komitesi'ne taraf oldukları ilk iki yıl içinde, daha sonra da her dört yılda bir rapor sunmakta, komite de bu raporları inceleyerek gerekli tavsiyelerde bulunabilmektedir. ${ }^{13}$

Engelli Haklarına İlişkin Sözleşme'nin atıfta bulunduğu Çocuk Haklarına dair Sözleşme'nin 23. maddesi, engelli çocukların haklarını konu almaktadır. Çocuk Haklarına dair Sözleşme'ye göre taraf devletler, engelli çocukların saygınlıklarını güvence altına almalı ve özgüvenlerini geliştirerek toplumsal yaşama etkin biçimde katılımlarını kolaylaştırmalıdırlar. Ayrıca engelli çocuklara bakım verenlere; engelli çocuğun eğitimi, tıbbi bakım ve rehabilitasyon hizmetleri, mesleğe hazırlık programları ve dinlenme/eğlenme olanaklarından etkin olarak yararlanmasını sağlamak üzere parasal yardım yapılmalı ve bu yardım çocuğun kültürel ve ruhsal yönü dahil bireysel gelişmesini gerçekleştirme amacı gütmelidir. Sözleşme, ayrıca taraf devletlere gelişmekte olan ülkelerin konuyla ilgili ihtiyaçları göz önünde bulundurularak uluslararası iş birliğine gidilmesi sorumluluğunu yüklemektedir. ${ }^{14}$

Ülkemizde de 2005 yılında yürürlüğe giren “Özürlüler Hakkında Kanun”da (5378 Sayılı Engelliler Hakkında Kanun) çocuklara yönelik maddeler yer almaktadır. $\mathrm{Bu}$ kanuna göre bahsedilen uluslararası sözleşmelerle aynı doğrultuda engelli çocuklara yönelik hizmetlerde çocuğun üstün yararının gözetilmesi esas olarak kabul edilmiştir. Kanun, engelliliğe dayalı her türlü ayrımcılığın önlenmesi ve engellilerin toplumda diğer bireylerle eşit koşullarda ve bağımsız olarak yaşamalarının gerekliliği üzerinde durur. Kanunda engelli çocuklarla ilgili bahsi geçen temel haklar; destek ve bakım, hizmete erişilebilirlik, habilitasyon ve rehabilitasyon, erken tanı ve koruyucu hizmetler, eğitim ve öğretimdir. $\mathrm{Bu}$ hizmetlerin sunumunun; Sağlık Bakanlığı, Aile, Çalışma ve Sosyal Hizmetler Bakanlığı ve Milli Eğitim Bakanlığı eşgüdümünde sürdürüldüğü belirtilmektedir. ${ }^{15}$

\section{Engellilerin Sosyal Sorunları ve Dışlanmışlık}

Engellileri sosyal hayata dâhil etmek adına çeşitli yasal düzenlemeler yapılmış, gerekli idari tedbirler alınmış ve bu doğrultuda çeşitli uygulamalar gerçekleştirilmiş olmasına rağmen konuyla ilgili kalıcı çözümler elde edilme konusunda yeterince yol alınamamıştır. Engelli bireyler, günümüzde hâlâ "dışlanan, kabul görmeyen, alay edilen ve küçümsenen insanlar" olarak görülmekte, bu tutum onların toplumdan dışlanmasına neden olmaktadır. $\mathrm{Bu}$ durum gerekli hizmetlere uygun şekilde erişimlerinin önüne geçmekte ve bir kısır döngü 
şeklinde toplumdan daha fazla dışlanmalarına yol açmaktadır. Bütün bunlar engelli bireyler için “ikinci bir engel” olarak gündeme gelmektedir. ${ }^{16-18}$

Engellilerin ayrımcılık ve dışlanmaya maruz kaldıkları alanların başında okul ve iş hayatı, ekonomik kaynaklara ve kamusal hizmetlere erişim gelmektedir. Engelli olma durumu, bireylerin eğitim ve iş olanaklarına erişimlerini ve sosyal güvenlik hizmetlerine ulaşımlarını kısıtlayarak onların yoksullaşmalarına neden olmaktadır. Engellilikle yoksulluk arasındaki ilişki çift yönlü olup her ikisinin yol açtığı sosyal dışlanma birbirlerinin etkisini artırmaktadır. Yoksulluk nedeniyle meydana gelen dezavantaj, engelli gençler arasında oldukça belirgin olup gelişmiş ülkelerde dahi kendini göstermektedir. BM verilerine göre engelli gençler dünya gençliğinin en yoksul ve marjinal kısmını oluşturmaktadır. ${ }^{16-18}$

Engellilerin topluma katılmalarının önündeki en büyük engellerden biri de ulaşım, fiziksel çevre ve konut sorunudur. Ulaşım sıkıntısı çok sayıda engelli gencin eğitim olanağını elinden almakta, hiç eğitim görememesine ya da eğitimini yarıda bırakmasına neden olmaktadır. $\mathrm{Bu}$ nedenlerle başarı düzeyleri olumsuz etkilenen gençler toplumda diğer bireylerin sahip olduğu pek çok avantajdan yoksun kalabilmektedir. Aynı zamanda engellilerin engellerine göre tasarlanmamış olan fiziksel çevre koşulları (yollar, kaldırımlar, kamu binaları, parklar ve bahçeler, okullar, içinde yaşanılan konutlar, ulaşım araçları vb.) bu bireylerin yaşadıkları sınırlanmayı daha da kuvvetlendirmekte ve hareket yeteneklerini daha da kısıtlayarak toplumdan dışlanma durumlarının artmasına neden olmaktadır. ${ }^{16-18}$

Sağlık sorunları açısından daha fazla risk altında bulunan engelli bireyler, engelli olmayan bireylerle kıyaslandığında aynı sağlık sorunlarından daha fazla etkilenmekte ve gereksinimleri farklılık göstermektedir. Bu durum engelli bireylerin sağlık sorunlarına yönelik yürütülen tedavileri daha karmaşık ve uzun süreli hâle getirmektedir. Örneğin; hareket konusunda engeli olan bir kişinin kalp damar hastalıklarından korunma amaciyla egzersiz yapması zor olabilmektedir. Ayrıca eşlik eden ruh sağlığı sorunları görülebilmektedir. Öte yandan bazı engellilerin yaşam boyu kullanmak durumunda oldukları ortez veya tekerlekli sandalye gibi bazı yardımcı tıbbi malzemeler maddi bir külfet getirebilmektedir. ${ }^{18}$

\section{Engelli Çocukların Sağlık Davranışları ve Konuyla İlgili Türkiye'de Yürütülen Çalışmalardan Örnekler}

Sağlık sorunlarının oluşmadan önlenmesi "sağlığın geliştirilmesi” bakış açısıyla mümkündür. $\mathrm{Bu}$ kavram kapsamlı bir sosyal ve politik süreci temsil etmekte; bireylerin beceri ve kapasitesini artırmaya yönelik eylemlerin yanında, sosyal, çevresel ve ekonomik koşulları değiştirerek bunların toplum ve bireysel sağlık üzerindeki olumsuz etkilerini hafifletmeye yönelik eylemleri içermektedir. Sağlığın geliştirilmesi, insanların sağlığın belirleyicileri üzerindeki kontrollerini artırmalarını, böylece kendi sağlıklarını iyileştirmelerini sağlama sürecidir. Sağlığın geliştirilmesi çabasının sürdürülmesi için katılım esastır. ${ }^{19} \mathrm{Bu}$ durum engelliler için bir dezavantaj olarak gündeme gelmektedir.

Engelli bireylere yönelik sağlık hizmetlerinin sınırlı olması, sağlık kuruluşlarının yeterli uygunlukta olmaması, sağlık kurumlarına ulaşım güçlüğü ve sağlık hizmetini talep etmekte ve sağlık sorunlarını dile getirmekte güçlükleri bulunması nedeniyle engellilerin sağlığın korunması ve geliştirilmesi hizmetlerinden daha 
fazla yararlanmalarının sağlanması önemlidir. ${ }^{20}$ Engelli çocuklara yönelik yapılan bir çalışmada ailelerin \%8,2'sinin sağlık ocağından hizmet alımında problem yaşadığı, \%31,8'inin sağlık hizmeti alımında engellerin olduğu saptanmıştır. ${ }^{21}$

Sağlık sorunlarının hemen tamamında engelli bireylere yönelik dezavantajlı durumlar gündeme gelmekte, bu kapsamda sağlığın geliştirilmesinde öncelikli olan sağlıklı beslenme, yeterli fiziksel aktivite, tütün, alkol ve madde kullanmama, cinsel sağlığın olumsuz etkilenmesi, şiddet ve istismar gibi konular öne çıkmaktadır.

\section{Sağlıklı Beslenme}

Bilişsel ve fiziksel gelişim ile beslenme arasındaki karşılıklı etkileşim göz önünde bulundurulduğunda engellilerin yeterli ve dengeli beslenmelerinin önemi açıç̧a ortaya çıkmaktadır. Engelli çocuklarda şişmanlıktan malnütrisyona kadar geniş bir yelpazede beslenme sorunları görüldüğü bilinmektedir. Sağlıklı çocukların \%25-30'unda görülen beslenmeye ilişkin sorunlar, engelli çocuklarda \%30-80'lere kadar çıkabilmektedir. Bu sorunlar sağlıklı çocuklarda çoğunlukla geçici olduğu hâlde engelli çocuklarda büyük ölçüde daimidir. Tanı ve tedavi olanaklarının artması eğitim, iletişim ve ortopedik bakım konularına büyük katkı sağladığı hâlde beslenme bozuklukları hastalığın kaçınılmaz bir sonucu olarak değerlendirildiği için bu konuya gereken önem verilmemektedir. ${ }^{22-24}$

Özellikle bozulmuş oral fonksiyonlar ve yutma bozukluğu ile giden nörolojik hastalıklar engelli bireyin kendi kendine yemek yemesini zorlaştırmakta, kusma veya aspire etme gibi sonuçlar doğurarak hem kendisi, hem de bakım veren için beslenme aktivitesini önemli ölçüde zorlaştırmaktadır. Engelli çocuklar aynı zamanda yiyecek tercihlerini tam olarak belirtememekte ve aileleri çocuğu sakinleştirmek için istediği her türlü yiyeceği (bisküvi, cips, şekerli yiyecekler vb) vermektedir. $\mathrm{Bu}$ faktörlere hareketlerindeki kısitlılıklar, kas becerilerindeki yetersizlikler ve sağlık kurumlarından yararlanmalarındaki zorluklar da eklenince beslenme sorunlarının önüne geçilememektedir. ${ }^{22-24}$

Konuyla ilgili Akdeniz Bölgesi’ndeki bir ilde bulunan Zihinsel Engelliler Okulu'nda yapılan bir çalışmada çocukların \%43,8'inde beslenme ile ilgili sorun olduğu, \%28,1'inin öğün atladığı, en çok atlanan öğünün öğle öğünü $(\% 55,6)$ olduğu ve BKİ'ye göre \%21,9'unun aşırı kilolu/şişman olduğu görülmüştür. ${ }^{25}$

Kayseri'de bir özel eğitim ve rehabilitasyon merkezinde eğitim alan 6-18 yaş arası 241 zihinsel engelli birey ile yapılan bir başka çalışmada çocukların sevdiği yiyecekler arasında şekerli gidalar $(\% 96,3)$, makarna $(\% 17,0)$, patates kızartması $(\% 14,5)$ ilk üç sırayı almaktadır. Çocukların \%15,4'ünün malnütrisyonlu, \%9,1'inin zayıf, \%44,4'ünün normal ağırlıklı, \%10,4'ünün hafif şişman, \%20,7'sinin şişman olduğu saptanmıştır. Aynı çalışmada ağır ve çok ağır zihinsel gerilik, kaşığı ağza götürememe, salya akması ve çiğnemede zorluk malnütrisyon için; annenin lise ve üzeri eğitimli olması, çocuğun kurumda öğle yemeği yemesi, ebeveynin çocuğunun normalden fazla yediğini ifade etmesi, salyasının akmaması şişmanlık için risk faktörü olarak belirlenmiştir. ${ }^{20}$

Ankara'daki bir görme engelliler ilköğretim okulunda öğrenim gören ve farklı düzeylerde görme kusuru bulunan 6-11 yaş arası 59 çocuğun dahil edildiği bir çalışmada çocuklarda 
beslenme durumu, diyet kalitesi ve fiziksel aktivite durumu incelenmiştir. Araştırmanın sonucunda DSÖ’nün BKİ Z-skor referans verilerine göre çocukların \%44'ünün hafif şişman/şişman; \%15,3'ünün ise zayıf/çok zayıf olduğu görülmüştür. Aynı araştırmada çocukların diyet kaliteleri de değerlendirilmiş ve Akdeniz tipi diyet ile uyumuna bakılmıştır. Bunu değerlendirmek için kullanılan KIDMED indeksi (Mediterranean Diet Quality Index), çocuk ve gençlerin ögünlerde ve öğün aralarında tükettikleri besinleri ve atlanan öğün olup olmadığı gibi beslenme alışkanlıklarını sorgulayarak elde edilen bir puandır. ${ }^{26}$ Katılımciların yalnızca \%22,9'unun Akdeniz tipi diyete uyumlu bir diyet tükettikleri, \%27,1'inin ise diyet kalitelerinin çok düşük olduğu belirlenmiştir. $^{27}$

Elazı̆̆ ilinde bulunan 3 özel eğitim okulunda eğitim gören 122 engelli öğrencinin ebeveynlerine anket uygulanarak yapılan çalışmanın sonuçlarına göre katılımcıların \%66,4'ünün üç ana öğün tükettiği, en çok atlanan öğünün öğle öğünü $(\% 55,7)$ olduğu ve çocuğun beslenmesi sırasında karşılaşılan en önemli sorunun çocuğun yemek beğenmemesi olduğu belirlenmiştir. Aynı çalışmada küçük yaşlarda düşük tartı sıklığı daha fazla iken, adëolesanlarda şişmanlığa eğilimin arttığı görülmüştür. 14 yaş ve üstü çocukların \%47'sinin vücut kitle indeksinin 85 . persentilin, \%15'inin ise 95. persentilin üzerinde olduğu bulunmuştur. ${ }^{28}$

\section{Fiziksel Aktivite}

Engelli bireylerde yetersiz fiziksel aktivite ve egzersiz düzeyi, şişmanlık ile sonuçlanabilen ve sağlığ1 tehdit eden bir duruma neden olabilmektedir. Bazı engel gruplarında kalp-damar hastalıkları oldukça yaygın olup fiziksel aktivite düzeyini etkileyerek yaşam tarzlarını etkilemektedir. Bu nedenle engelli çocuklara engel türüne uygun, doğru fiziksel aktivitenin önerilmesi ve öğretilmesi büyük önem taşımaktadır. Fiziksel aktivite, sağlıklı vücut ağırlığını korumanın yanı sıra ağırlık taşımak ve kaldırmak, merdiven inip çıkmak, iyi bir duruşu devam ettirmek, işle ilgili aktiviteleri yerine getirmek gibi günlük yaşam faaliyetlerinde de performansı artıracak bir kas kuvveti sağlayacaktır. ${ }^{24}$ Öğrenme güçlüğü olan 40 çocukla yürütülen bir çalışmada Uluslararası Fiziksel Aktivite Anketi ve Öğrenme Güçlüğü Tanıma Anketi kullanılarak yapılan analizlerde öğrencilerin sadece \%12'sinin yeterli fiziksel aktivite düzeyine sahip olduğu ve fiziksel aktivite ile öğrenme yeteneği arasında anlamlı bir ilişki bulunduğu saptanmıştır. ${ }^{29}$

\section{Ă̆ız Hijyeni}

Beslenme ile ilgili sorunlardan biri de diş firçalama başta olmak üzere ağız hijyeni gerekliliklerine dikkat edilmemesidir. $\mathrm{Bu}$ durumun temel nedeni engelli bireylerin mental ve motor fonksiyonlarındaki yetersizlikler olmakla beraber bakım verenin farkındalığının ve eğitiminin yetersiz olması, karbonhidrat alım sıklıklarındaki artış, kas ve eklem problemlerine bağlı hijyen eksikliği ve çiğneme zorlukları da ağı hijyenini etkilemektedir. ${ }^{30,31}$ Özer ve arkadaşlarının özel bir eğitim kurumunda eğitim gören 7-20 yaş arası çocuklarla yürüttüğü bir çalışmada çocukların \%20'sinde kişisel hijyenin kötü olduğu saptanmış, diş çürüğü yüzdesi ise $\% 80$ olarak bulunmuştur. ${ }^{28}$ Farklı IQ (Intelligence Quotient) seviyelerinin, zihinsel engelli çocuklarda ağı sağlığını etkileyebileceği düşünülerek aile ve öğretmenlere verilen ağız hijyeni eğitiminin farklı IQ seviyelerine sahip çocukların ağız sağlığı durumu üzerindeki etkilerinin karşılaştırılması amacıyla yapılan bir 
başka çalışmada bu eğitimin etkili olmadığı saptanmıştır. ${ }^{30}$

Samsun ilinde bulunan bir fiziksel engelliler okulunda eğitim gören 171 fiziksel engelli çocuk ile yapılan bir çalışmada ağız temizliği yönünden işitme engelli çocukların en iyi, ortopedik engelli çocukların en kötü puanları aldıkları ve çürük prevalansı ile fiziksel engel türü arasında bir ilişki olduğu tespit edilmiştir. İşitme engelli çocuklarla görsel iletişim daha rahat kurulabildiği için bu çocukların diş firçalamayı daha kolay öğrendikleri ve diğer gruplardaki çocuklara göre ağız temizliğine daha fazla önem verdikleri düşünülmüştür. Bahsi geçen çalışmada görme engelli bireylerin ortopedik engelli bireylerden daha iyi, işitme engelli bireylerden daha kötü bir ağı bakımına sahip oldukları belirlenmiştir. Görme engelli bireylerde hasta ve bakıcısının ağız hastalıkları konusunda bilgilendirilmesi, yazılı ve görsel bilgiye ulaşımları kısıtlı olan bu bireylere verilecek eğitimin oldukça basit bir şekilde, sözlü ve uygulamalı olarak ve sık aralıklarla tekrarlanarak verilmesi önem kazanmaktadır. ${ }^{31,32}$ Gülhane Askeri Tıp Akademisi bünyesinde bulunan engelli çocuklar okuluna devam etmekte olan 87 engelli çocuğun diş çürüğü yüzdelerini ve ağız sağlığı durumlarını tespit etmek amacıyla yapılan bir başka çalışmada ise yine engel türlerinin ağız temizliğini istatistiksel olarak anlamlı şekilde etkilediği; ağız temizliği yönünden otistik çocukların en iyi, serebral palsi hastası çocukların en kötü skorlara sahip oldukları tespit edilmiştir. $^{33}$

\section{Tütün Kullanımı}

Tütün ve tütün ürünleri kullanımı günümüzde “epidemi” hâlini almış olan çok ciddi bir sağlık sorunudur. Engelli bireylerde tütün kullanım yüzdesi, toplumdaki genel görülme yüzdesinden daha düşük olmakla beraber, bu bireyler de tütün kullanımını stresle baş etme yolu olarak görmektedirler. Literatürde çocuklarla ilgili çalışma bulunamamış olmakla birlikte konuyla ilgili bulunan sınırlı sayıdaki araştırmalardan birinde İstanbul Bağcılar Belediyesi Engelliler Sarayı'nın hizmetlerinden yararlanan 15-42 yaş arası bedensel engelli 47 gönüllü arasından 8 kişi aktif sigara içicisi olarak saptanmıştır. Aktif olarak sigara içenler ve sigarayı bırakmış olan engelli bireylerin arasında ilkokul yıllarında sigaraya başlama yüzdesi \%50 olarak saptanmıştır. Arkadaş faktörü sigara içmede rol oynayan en önemli etken $(\% 78,7)$ olarak ifade edilmiştir. ${ }^{34}$

\section{Sağlıklı Cinsel Davranışlar}

Engelli bireyler, engelli olmanın getirdiği fiziksel ve psikososyal sıkıntıların yanı sira, cinsel sorunları engelli olmayan bireylere göre daha fazla yaşamaktadırlar. Cinsellik, yaş, cinsiyet veya gelişim düzeyi ne olursa olsun önemli bir insan hakkı olmakla birlikte sadece cinsel ilişkiden ibaret olarak düşünülmemelidir. Ancak engelli bireylerin de cinsel gereksinimleri olduğu çoğu zaman göz ardı edilmektedir. Engelli olma durumu genellikle menstruasyonu, fertiliteyi ya da cinsel yanıtı etkilememekte, fakat engelli bireyler engellerinin türüne göre cinsel birliktelik deneyimleri yaşama ve sürdürmede, cinsel istek açısından ve sosyal nedenlerle, evliliği ve ebeveynliği yürütmede önemli sorunlar yaşayabilmektedir. Aşırı koruyucu aile ve buluşma mekanlarının yokluğu, cinsellik konusunda bilgi eksikliği ve bilgi edinmedeki engeller cinsel davranışlarını etkileyebilmektedir. ${ }^{35-}$ 37

Engelli tüm bireylerin, cinsel sağlıklarını korumak ve geliştirmek için eğitim ve danışmanlık almaları önemlidir. Ancak sorunların en yoğun olarak yaşandığı dönem cinsel kimliğinin kazanıldığı adëolesan dönemdir. Bu dönemde hızla 
değişen beden yapısı ve hormonal durumu cinsel kimliğinin oluşmasını sağlar. Bir engele sahip olup olmamak bu durumu değiştirmemektedir. $\mathrm{Bu}$ nedenle adölesanların cinsel eğitimi, engelli bireylerde önem kazanmaktadır. ${ }^{35,36}$

\section{İhmal, İstismar ve Şiddete Uğrama}

Son yıllarda engellilere yönelik eylemler içinde en çok dikkati çeken sorunlardan biri de engellilere yönelik ihmal ve istismardır. $\mathrm{Bu}$ durumların yaşanması engelli bireyin fiziksel ve ruhsal sorunlar yaşamasına, mevcut engel durumlarının daha da artmasına veya hayatlarını kaybetmelerine yol açabilmektedir. $\mathrm{Bu}$ konuyla ilgili temel sorun yaşam faaliyetini sınırlayan bir veya birden fazla fiziksel veya zihinsel yetersizliği olan bireyin herhangi bir istismar durumunda tepki vermekte kısıtlı kalmasıdır. Ayrıca herhangi bir şiddet durumunda yetkililere bildirimde bulunmaları da zorluk oluşturur. Örneğin; görme engelli birinin yaşadığı şiddette şiddet uygulayanı tarif etmesinde önemli sorun yaşanabilmektedir. ${ }^{38}$

İhmal ve istismar mağdurları kategorisinde yer alan en temel grup şüphesiz çocuklardır. Engelli Bireylere Yönelik Fiziksel-Cinsel Şiddet, İstismar ve Kötü Muamele Olayları İzleme Raporu (2016) verilerine göre medya taraması, bilgi edinme başvuruları, nitel araştırma, mahkeme kararları taraması ve mevzuat irdelemesi sonucu ulaşılan istismara uğramış 391 engelliden alınan verilerin analizi sonucu 18 yaşın altındaki mağdur engelli bireylerin bütün yaş grubu mağdurlarının \%36,1'ini oluşturduğu saptanmıştır. ${ }^{39}$

"Çocuk istismarı ve ihmali, anne, baba ya da bakıcı gibi bir erişkin tarafından çocuğa yöneltilen, toplumsal kurallar ve profesyonel kişilerce uygunsuz ya da hasar verici olarak nitelendirilen, çocuğun gelişimini engelleyen ya da kısıtlayan eylem ve eylemsizliklerin tümüdür". ${ }^{40}$ İstismar ve şiddete tüm çocuklar maruz kalmakta, fakat çocuğun engelli olması özellikle de zihinsel engelli olması bu maruz kalımı artırmaktadır. ${ }^{41}$

Özellikle zihinsel engelli çocuklar, sevme ve sevilmeyi hayati bir ihtiyaç olarak gördükleri ve akıl yürütme kabiliyetleri zayıf olduğu için cinsel ilişki için yapılacak bir teklifi ya da bir cinsel yakınlaşmayı kolay ve sessiz bir şekilde kabul edebilmektedirler. Zihinsel engelli gençlerin de cinsiyet hormonları normal düzeninde çalışmakta ve eğer fiziksel bir bozuklukları bulunmuyorsa cinsel gelişimleri normal düzende ilerlemektedir. $\mathrm{Bu}$ nedenle bu gençler normal gelişim gösteren gençlerle aynı cinsel güdülere sahiptir. Ancak cinsel içerikli davranışlarını kontrol edemeyebilmekte, yer ve zamanını ayarlayamamaktadırlar. Bunun sonucu olarak yaşıtlarından daha fazla cinsel içerikli davranışlar sergileyebilmekte ve bu da onları cinsel sömürüye açık hâle getirebilmektedir. Ayrıca bu çocukların kendilerini sözel olarak ifade etmekte yetersiz olmaları da herhangi bir istismar durumunun ortaya çıkmasında bir engel olarak rol oynamaktadır. ${ }^{35,36,41}$

Konuyla ilgili yapılan bir çalışmada 20052015 yılları arasında basına yansıyan engelli çocuklara yönelik istismar vakaları incelenmiştir. Ulaşılan haberlerde istismara uğradığı saptanan 278 istismar olgusunun $\% 42,5$ 'u reşit olmayan bireylerden oluşmakta, bu grubun ise \%60,2'si 1418 yaşında bulunmaktadır. Büyük çoğunluğu $(\% 69,7)$ zihinsel engelli olup saptanan en fazla istismar türü cinsel istismardır $(\% 88,1)$. Bireylerin \%31,3’ünün birden fazla kişinin istismarına maruz kaldı $\breve{g}_{1} ; \% 34,1$ 'inin ise evlerinde istismara uğradı $\breve{g}_{1}$ saptanmıştır. $^{42}$

Engelli çocukların akran zorbalığına maruz kaldıkları da görülmektedir. Kaynaştırma eğitimine 
devam eden öğrencilerin akranları ile ilişkilerinde karşılaştıkları sorunları belirlemek amacıyla 20082009 öğretim yılında Konya ili Sarayönü ilçesinde 9 resmi ilköğretim okulunda kaynaştırma eğitimine devam eden 27 öğrenciyle görüşülerek gerçekleştirilen nitel bir araştırmada, engelli öğrencilerin normal öğrenciler tarafından şiddete ve dışlanmaya maruz kaldıkları belirtilmektedir. Aynı zamanda bu çocukların sayısal ve sözel derslerde yeterli başarıyı gösteremedikleri ve sınıf içi iletişim ve etkileşimlerinin yetersiz olduğu vurgulanmaktadır. ${ }^{43}$

Konya il merkezinde ikamet eden 0-18 yaş zihinsel ve bedensel engelli 258 çocuk ile benzer sosyodemografik özelliklere sahip 258 engelli olmayan çocuğun kontrol grubu olarak alındığ1 karşılaştırmalı bir çalışmada tam aşılı olma yüzdesinin engelli çocuklarda \%87,6; kontrol grubunda ise \%97,3 olduğu görülmüştür. $\mathrm{Bu}$ da çocuk ihmali olarak değerlendirilebilecek bir durumdur. $^{44}$

Bütün bu bahsedilen durumların yanı sıra engelli çocukların annelerinin aşırı koruyucu tavır takınmaları da çocuğun bağımsız bir yaşam sürmesini kısıtlayan bir faktördür. Üç özel eğitim ve rehabilitasyon merkezi ve bir üniversite hastanesi serebral palsi (SP) polikliniğine gelen 718 yaş grubunda SP'li çocuğa sahip olan 48 annenin katıldığı bir çalışmada yüz yüze görüşme tekniği ile toplanan veriler analiz edilmiş, öz bakım puan ortalaması 100 üzerinden 37,0 24,3 olup, öz bakım beceri düzeyi oldukça düşük olarak bulunmuştur. Annelerin öz bakıma izin verme puanları 10 puan üzerinden $5,1 \pm 3,1$; öz bakımı destekleme puanları ise $3,6 \pm 2,8$ olarak yetersiz bulunmuştur. Annelerin daha çok motor beceri isteyen öz bakım davranışlarına daha az izin verdikleri görülmüştür. ${ }^{45}$

\section{Sağlığı Geliştirme için çok Sektörlü Yaklaşım ve Engelli Çocukların Topluma Kazandırılması}

Engelli çocukların sağlığının geliştirilmesi ve topluma kazandırılmasının temelinde çocuğun eğitimi, ailelerin eğitimi ve engelli çocuğa sağlık ve bakım hizmetlerinin bütünlüklü bir şekilde verilmesi yatmaktadır. $\mathrm{Bu}$ bağlamda çocukların sağlık ve eğitim hizmetlerine ulaşımlarını optimal düzeye çıkaracak önlemlerin alınması büyük önem taşımaktadır.

\section{Engelli Çocuğun Eğitimi}

Eğitim hakkı Anayasa'nın 42. maddesinde yer alan "Hiçbir birey eğitim ve öğrenim hakkından yoksun bırakılamaz" hükmü ile güvence altına alınmıştır. ${ }^{46}$ Çocuğa tanı konulduktan sonra özel eğitim hizmetlerinden yararlanabilmesinin sağlanması için yetkili bir sağlık kuruluşundan "Engelli Sağlık Kurulu Raporu" alması ve eğitimin nasıl alınacağ konusunda planlama yapılabilmesi için her şehirde bulunan Rehberlik Araştırma Merkezi'ne (RAM) başvurması gerekmektedir. Yapılan planlamaya göre özel eğitim gerektiren çocuklar ya eğitimlerini normal gelişim gösteren çocukların devam ettiği resmi veya özel okullara (kaynaştırma sınıfi) ya da özel eğitim sınıflarına alınmaktadır. Ülkemizde eğitime ihtiyacı olan engellilere yönelik eğitimden Milli Eğitim Bakanlığı sorumludur. ${ }^{47,48}$

Tanı konulmasıyla başlayan özel eğitim sürekli olmalı, sosyal ve fiziksel çevrenin şartları ve olanakları göz önünde bulundurularak ve bireyselleştirilerek planlanmalıdır. Sürecin her aşamasında bireysel performans değerlendirilerek sonraki aşamaların planlanmasında dikkate alınmalıdır. Verilecek eğitimin temel yaşam becerileri geliştirecek nitelikte olması önem taşımaktadır. ${ }^{47,48}$ 


\section{Ailelerin Eğitimi}

Engelli eğitiminde; çocukların eğitimlerinin yanı sıra ailelerin de eğitilmesi büyük önem taşımaktadır. Bu kapsamda ailenin sadece verilen eğitimi uygulayan değil, çocuğun eğitim sürecine katkı sağlayan nitelikte olması sağlanmalıdır. $\mathrm{Bu}$ amaçla, aileler çocukların sağlığını geliştirmelerinin önemi konusunda bilgilendirilmeli, verilecek eğitim çocuğun engel durumu ile ilgili ailenin bilmesi gereken tüm bilgileri içermeli ve ailelerin çocuğun sağlığının geliştirilmesi için bireysel müdahalelerin öneminin farkına varmaları ve yaşama geçirmeleri sağlanmalıdır. Aile ve engelli çocuğun eğitim ve sağlik gereksinimleri tam olarak belirlenmeli ve onlara destek olmak amacıyla doğru yönlendirmeler yapılarak ailenin çocuğa yönelik eğitimin planlanmasından başlanarak tüm eğitim süreci boyunca aktif katılımı sağlanmalıdır. Bu konuya ilişkin aile danışmanlıklarının sunumu son derece önemlidir. ${ }^{47,48}$

\section{Sağlık Hizmetleri ve Rehabilitasyon}

Engelli çocukların sağlı̆̆ının geliştirilmesine yönelik yaklaşım tüm sağlık kuruluşlarının hizmet kapsamı içinde yer almalıdır. Herhangi bir sorunu nedeniyle gelen engelli çocuğun sağlığının geliştirilmesi ve korunmasına yönelik durumu değerlendirilmeli, olumlu bir şekilde gelişmesi için yapılması gerekenlerin aileyle paylaşımı ve kolaylaştırıcı önerilerin sunulması sağlanmalıdır. Özellikle motor problemi olan çocukların rehabilitasyon hizmetlerinde bu konuda çalışan uzman hekimler, fizyoterapist, ergoterapist, psikolog, özel eğitim uzmanı, çocuk gelişim uzmanı, sosyal danışman, öğretmenler, protez-ortez teknikerleri gibi konusunda uzman ve deneyimli kişilerin ekip çalışması yapması gerekmektedir.
Rehabilitasyonun etkili olacak şekilde zamanında başlatılabilmesi için erken tanı çok büyük önem taşır. Ayrıca çocukların bağımsız hareket etmelerine yardımcı olarak yaşamlarını kolaylaştırmak amacıyla yardımcı araç gereç, protez ve ortez gibi destek ekipmanlar sağlanmalıdır. Rehabilitasyon merkezleri ülke genelinde yaygınlaştırılarak ihtiyaç duyan tüm çocuklara bu merkezlere ulaşabilme ve tedavi olabilme şansı verilmelidir. ${ }^{47,48}$

Ailelerin fiziksel ve ekonomik şartları göz önünde bulundurularak evde çocukların mentalmotor gelişimleri için uygulayacakları yöntemlerin uygulamalı olarak anlatılması gerekmektedir. Ayrıca yaşamlarını kolaylaştırıcı ev ortamı (evin konumu, iç düzenleme) sağlanması için devlet tarafından gerekli mali destek sağlanmalıdır. Rehabilitasyon planlaması kişisel yetenekler, kişinin yaşam biçimi ve beklentileri dikkate alınarak yapılmalıdır. Çocukların içinde bulundukları durumdan dolayı yaşayabilecekleri psikolojik sorunlar göz önünde bulundurularak psikososyal olarak desteklenmelerine yönelik müdahale programları geliştirilmeli; aileler şiddet, istismar ve ihmal konusunda bilgilendirilerek çocukların sosyal olarak topluma katılımlarına katkı sağlanmalıdır. ${ }^{47,48}$

\section{Mimari ve Çevresel Düzenlemeler}

Engellileri başkalarının yardımına ihtiyaç duymadan kent yaşamı ile bütünleştirmek için “engelsiz fiziksel çevreler oluşturmak” ve mevcut çevrelerin "niteliğini iyileştirmek”, “erişebilirliğini artırmak" hedeflenmelidir. Engelli çocukların, yaşamlarını kolaylaştırıcı çevresel müdahalelerin yanı sıra sağlı̆̆ını geliştiren olumlu çevre koşullarına sahip olmalarına ilişkin yaklaşımlar güçlendirilmelidir. Konut alanlarına yönelik 
düzenlemelerin yanı sıra kentin merkez alanına, çalışma alanlarına, rekreasyon alanları ve yeşil alanlara ve ulaşıma yönelik düzenlemeler yapılmalıdır. Eğitim kuruluşlarındaki bina tasarımları engelli veya engelsiz tüm çocukların bir arada eğitim alabilmesini kolaylaştıracak şekilde yapılmalıdır. Kamu hizmetlerinden daha rahat yararlanabilmeleri için kamu kurumlarının bina girişleri, katlar arası ulaşım, koridor, kapılar gibi iç düzenlemeler engellilerin kullanımına uygun hâle getirilmelidir. Ayrıca rekreasyon alanları ve parklara engelli çocukların kolay fiziksel erişiminin sağlanması; tiyatro, konser, sergi, sinema ve alışveriş merkezleri gibi genel kullanıma açık binaların engellilerin ulaşımına uygun hale getirilmesi hedef olmalıdır. Taşımacılık ve trafik güvenliği konularında da gerekli önlemler alınmalı ve kolaylıklar sağlanmalıdır. ${ }^{49}$

Engellilerin sık olarak başvurdukları sağlık kuruluşlarının iç ve dış mekânlarının mimari ve çevresel düzenlemelerinde de Türk Standartları Enstitüsü (TSE) standartları esas alınmalıdır. Bu kapsamda tuvalet, lavabo, müracaat bankosu vb. gibi ortak alanlarda ve asansörlerde her engel grubundaki kişilerin algılayabileceği şekilde yazıll, sesli ve görsel yönlendirmeler yapılmalı, bu alanlar her engel grubuna hitap edecek şekilde düzenlenmelidir. Bunu sağlamak amacıyla görme engelliler için ortak alanlarda takip izi oluşturulmalı ve bu bireylerin gerekli bilgilere ulaşabilmeleri için Braille alfabesi kullanılmalı, işitme-konuşma engelliler için ise işaret dili bilen personel çalıştırılmalıdır. Ayrıca tekerlekli sandalye transferini kolaylaştıracak düzenlemeler yapılması önem taşımaktadır. Engelli hastalara işlemlerinde yardımcı olacak refakatçi personel (hostes hizmeti) temin edilmesi de hizmet alımlarını kolaylaştıracaktır. Sağlık çalışanıyla engellilerin iletişiminin sağlıklı olmasına katkı sağlamak için sağlık kuruluşlarında sağlık hizmet sunuculara verilen hizmet içi eğitimlerde engelliliğe ilişkin konular da ele alınmalıdır. Tüm bu konularla ilgili gerekli yasal düzenlemeler yapılmalı, yasalarda yer alan düzenlemelerin uygulanması sağlanmalı, aksi takdirde cezai yaptırımlara başvurulmalıdır Aileler ve kurumlar, sağlıklı beslenme, fiziksel aktivite ve ruhsal sağlığı geliştirecek olumlu yaşam koşullarının sağlayarak çocukların sağlığını geliştirmeye katkı sunmalıdırlar. ${ }^{47,48}$

\section{Politik Önlemler}

Yukarıda belirtilen tüm hak ve özgürlüklerin kullanılmasının ve yaşamın tüm alanlarına katılımın ön koşulu erişilebilirliktir. Sorunu kapsayan tek bir ulusal eylem planının yanı sıra her kurum ve kuruluşun kendi sorumluluk ve hizmet alanı içinde engellilerin hak ve hizmetlere erişimde yaşadığ sıkıntıları çözmeye yönelik politika, plan ve programlar geliştirmesi önem taşımaktadır. Engellilerin yaşama katılabilmeleri için sağlığının korunması ve geliştirilmesine yönelik yapılması gerekenlerin de eylem planları, müdahaleler içinde yer alması sağlanmalıdır. Sağlığın geliştirilmesinde bireysel gelişim ve olumlu çevrenin önemi tüm sektörler tarafindan benimsenerek, müdahaleler içinde yer alması sağlanmalıdır; öncelikli olarak Sağlık Bakanlığı, Ulaştırma ve Altyapı Bakanlığı, Çevre ve Şehircilik Bakanlığı, İçişleri Bakanlığı, Aile, Çalışma ve Sosyal Hizmetler Bakanlığı ve Milli Eğitim Bakanlıklarında konuya yönelik hizmet birimleri kurulmalıdır. Yerel idarelerin de sorunun çözümündeki sorumluluklarına yönelik standartlara uymaları sağlanmalı, gerekirse denetlenmelidir. Engellilerin hak arama yollarını kullanma konusundaki güçlükleri de göz önünde bulundurularak basit yollarla haklarını arayabilecekleri, şikayetlerini bildirebilecekleri kanallar açılmalıdır. Aynı zamanda ülkemizde 
konuyla ilgili az sayıda çalışma bulunduğu için sağlık alanında engellilere yönelik yapılan araştırmaların artırılması da önerilmektedir. ${ }^{49,50}$

\section{SONUÇ}

Sosyal dışlanmışlık, hizmetlere erişim güçlüğü ve sağlık sorunlarının ayrıntılı ve karmaşık olması durumları göz önünde bulundurulduğunda engelli çocuklar incinebilirliği en yüksek gruplardan birini oluşturmaktadır. Sağlık sorunlarının pek çoğunda engelli bireylere yönelik dezavantajlı durumların gündeme geldiği düşünüldüğünde konuyla ilgili etkili ve kalıcı önlemlerin alınması büyük önem taşımaktadır. Bu kapsamda çocukların ve ailelerin eğitimi ve engelli çocuğa sağlık ve bakım hizmetlerinin kapsamlı ve kapsayıcı bir şekilde verilmesi, çocukların sağlıklarının geliştirilmesi, sosyal ve politik süreçlere katılımlarının en iyi düzeye çıkarılabilmesine katkıda bulunacaktır.

\section{KAYNAKLAR}

1. World Health Organization. Health Topics. Disabilities.

https://www.who.int/topics/disabilities/en/

(Erişim:29.01.2019)

2. World Health Organization. World Disability Action Plan 2014-2020. WHO, 2015 https://apps.who.int/iris/bitstream/handle/10665/19 9544/9789241509619_eng.pdf?sequence $=1$

(Erişim:30.01.2019)

3. United Nations Development Programme. Evaluation of Disability- Inclusive Development at UNDP, 2016 http://web.undp.org/evaluation/evaluations/thematic /disability.shtml (Erişim: 30.01.2019)

4. Başbakanlık Devlet İstatistik Enstitüsü Başkanlığı. Türkiye Özürlüler Araştırması, Ankara, 2002 https://kutuphane.tuik.gov.tr/pdf/0014899.pdf (Erişim: 30.01.2019)

5. TC. Aile Çalışma ve Sosyal Güvenlik Bakanlığı. Engelli ve Yaşlı Hizmetleri Genel
Müdürlüğü. Özürlülerin Sorun ve Beklentileri Araştırmas1, 2010. https://eyh.aile.gov.tr/ozurlulerin-sorun-vebeklentileri-arastirmasi-kitabi-2010 (Erişim:25.01.2019)

6. Aslan M, Şeker S. Engellilere yönelik toplumsal algı ve dışlanmışlık (Siirt Örneği). Sosyal Haklar Uluslararası Sempozyumu, Bursa, 2013, s.449-463.

7. Engelsiz Yaşama Derneği. Türkiye'de ve Dünya'da Engelliler.http://ey-der.com/anasayfa/turkiye-ve-dunyada-engelliler/ (Erişim: 30.01.2019)

8. United Nations International Children's Emergency Fund (UNICEF). Disabilities. https://www.unicef.org/disabilities/ (Erişim: 02.02.2019)

9. World Health Organization. Fact Files. 10 facts about disabilities. https://www.who.int/features/factfiles/disability/en/ (Erişim Tarihi:01.02.2019)

10. Sevinç İ, Çay M. Fiziksel engelli bireylerin üniversite eğitimi sırasında karşılaştıkları sorunlar (Akdeniz Üniversitesi örneği). Selçuk Üniversitesi Sosyal ve Teknik Araştırmalar Dergisi 2017;13:219-238.

11. Engelli Haklarına İlişkin Sözleşme (Türkçe Çeviri) http://www.resmigazete.gov.tr/eskiler/2009/07/200 90714-1.htm (Erişim: 04.01.2019)

12. İstanbul Bilgi Üniversitesi. İnsan Hakları Hukuku Uygulama ve Araştırma Merkezi. Uluslararası Hukuk ve Denetim Usulleri. Birleşmiş Milletler. Sözleşmeler. İnsan Haklarına İlişkin Sözleşme.

https://humanrightscenter.bilgi.edu.tr/tr/content/132 -engellilerin-haklarna-iliskin-sozlesme/ (Erişim: 04.01.2019)

13. İstanbul Bilgi Üniversitesi. İnsan Hakları Hukuku Uygulama ve Araştırma Merkezi. Uluslararası Hukuk ve Denetim Usulleri. Birleşmiş Milletler. Denetim Usulleri. Antlaşmaya Dayalı Denetim Usulleri. Engelli Hakları Komitesi. https://humanrightscenter.bilgi.edu.tr/tr/content/146 -engelli-haklar-komitesi/ (Erişim: 04.01.2019) 
14. UNICEF. Çocuk Haklarına Dair Sözleşme. https://www.unicef.org/turkey/crc/_cr23d.html (Erişim: 05.01.2019)

15. Engelliler Hakkında Kanun. http://www.mevzuat.gov.tr/MevzuatMetin/1.5.5378 .pdf (Erişim Tarihi: 05.01.2019)

16. Köten E, Erdoğan B. Engelli gençler, sosyal dışlanma ve internet. İstanbul Gelişim Üniversitesi Yayınları, 2014, s.19-28.

17. Genç Y. Engellilerin sosyal sorunları ve beklentileri. Sosyal Politika Çalışmaları Dergisi 2015;15(3):65-92.

18. Karip S. Engelli bireylerin sağlık hizmetlerine ulaşabilirlik düzeylerinin belirlenmesi: Konya örneği. Selçuk Üniversitesi, Sağlık Bilimleri Enstitüsü, Sosyal Hizmet Anabilim Dalı, Yüksek Lisans Tezi, Konya, 2016, s.19-25.

19. T.C. Sağlık Bakanlığı Temel Sağlık Hizmetleri Genel Müdürlüğü Sağlığın Geliştirilmesi ve Teşviki Sözlüğü. Ankara, 2011. https://sbu.saglik.gov.tr/Ekutuphane/kitaplar/Sa\%C $4 \% 9 \mathrm{~F} 1 \% \mathrm{C} 4 \% \mathrm{~B} 1 \% \mathrm{C} 4 \% 9 \mathrm{~F} \% \mathrm{C} 4 \% \mathrm{~B} 1 \mathrm{n} \% 20 \mathrm{Te} \% \mathrm{C} 5 \%$ 9Fviki\%20S\%C3\%B6zl\%C3\%BCk.pdf (Erişim: 07.03.2019)

20. Özgüven L. Zihinsel engelli çocuk ve adolesanların, beslenme durumu ve alışkanlıkları. Erciyes Üniversitesi, Sağlık Bilimleri Enstitüsü, Halk Sağlığı Anabilim Dalı, Yüksek Lisans Tezi, Kayseri, 2015, s.43-69.

21. Bodur S, Durduran Y. Konya'da engelli çocukların sağlık hizmetlerinden yararlanma ve beklenti durumu. Genel Tip Dergisi 2009;19(4):169-175.

22. Garipağaoğlu M. Engelli çocuklarda beslenme, II. Ulusal Sosyal Pediatri Kongresi; 7-11 Kasim, 2012; İstanbul. http://www.sosyalpediatri.org.tr/uploads/engellicocuklarda-beslenme-pdf-525k.pdf (Erişim:14.05.2019)

23. Köksal G. Engellilerde beslenme. Sağlık Bakanlığı Yayınları, Ankara, 2012,s.11.

24. Kanbaş E. Zihinsel Engelli Çocuklarda Obezite https://www.zicev.org.tr/zihinsel-engellicocuklarda-obezitemakale-2 (Erişim:06.02.2019)
25. Özbaş S, Uskun E, Küçüksoku B, Hocaoğlu Ü, Akalın S, Özbaş H. Eğitilebilir Zihinsel Engelli Çocukların Besin Tüketim Kayıtlarına Göre Beslenme Durumları. Akademik G1da 2018;16(2):192-196.

26. Erol E, Ersoy G, Pulur A, Özdemir G, Bektaş Y. Evaluation of the Mediterranean Diet Quality Index (KIDMED) in adolescents in Turkey. Journal of Human Sciences 2010;7(1):647-664.

27. Ilgaz F, Aksan A, Özcebe H. Görme engelli çocuklarda beslenme durumu, fiziksel aktivite ve diyet kalitesinin değerlendirilmesi. Journal of Food and Health Science 2016;2(2):90103.

28. Özer I, Öner D, Sevim H, Karaağaç AT, Mollaoğlu B, Abbasoğlu K, Kavurmacı D. Hafif zihinsel geriliği olan çocuklarda genel sağlık durumu değerlendirmesi. ADÜ Tıp Fakültesi Dergisi 2003;4(1):9-12.

29. Demirci, N, Engin AO, Özmen, A. The influence of physical activity level on the children's learning ability of disabled children having difficulties in learning. Procedia-Social and Behavioral Sciences, 2012;69:1572-1578.

30. Yetkin Ay Z, Eroğlu E, Türkaslan S, Bozkurt YF, Yılmaz HR. Aile ve öğretmenlere verilen oral hijyen eğitiminin mental engelli çocukların ağız sağlığı durumu üzerine etkisi. Süleyman Demirel Üniversitesi Tıp Fakültesi Dergisi, 2005;12:17-22.

31. Sarı ME, Kalyoncuoğlu E, Çankaya S. Fiziksel engelli çocukların ağız ve diş sağlığ yönünden değerlendirilmesi. Atatürk Üniversitesi Diş Hekimliği Fakültesi Dergisi 2012;1:7-13.

32. Köse O, Dilsiz A, Arabacı T. Görme engelli bireylerde ağı sağlığı. Atatürk Üniversitesi Diş Hekimliği Fakültesi Dergisi 2014;8:56-60.

33. Çokpekin F, Köymen G, Başak F, Akbulut E, Altun C. Engelliler okuluna devam eden çocukların ağı diş sağlığı yönünden değerlendirilmesi. Gülhane Tip Dergisi 2003;45(3):228-232.

34. Yildırım E, Yıldız A, Mutluay F, Algun C. Engelli bireylerde sigara kullanımının değerlendirilmesi. Hacettepe Faculty of Health Sciences Journal 2015;1(1):1-7. 
35. Cangöl, E, Karaca PP, Aslan E. Engelli bireylerde cinsel sağlık. Androloji Bülteni 2013;53(1):141-146.

36. Boyacioğlu NE, Karaçam ZD, Özcan NK. Engellere rağmen cinsellik: zihinsel yetersizliğe sahip çocuklarda cinsellik. Sağlık Bilimleri ve Meslekleri Dergisi 2018;5(2):75-80.

37. Elbozan Cumurcu B, Karlıdağ R, Han Almış B. Fiziksel engellilerde cinsellik. Psikiyatride Güncel Yaklaşımlar 2012;4(1):84-98.

38. Metin A, Bilgin NG, Yildırım V. Bakımevinde ölüm ile sonuçlanan engelli çocuğa yönelik fiziksel istismar olgusu. Adli Tıp Bülteni 2014;19(3):193-197.

39. Toplumsal Haklar ve Araştırma Derneği. Engelli Bireylere Yönelik Fiziksel-Cinsel Şiddet, İstismar ve Kötü Muamele Olayları İzleme Raporu, 2016

http://www.engellihaklariizleme.org/tr/files/belgele r/fiziksel_cinsel_siddet_izleme_raporu_2016.pdf (Erişim: 07.03.2109)

40. Taner Y, Gökler B. Çocuk istismarı ve ihmali: psikiyatrik yönleri. Hacettepe Tıp Dergisi 2004;35: 82-86.

41. Yıldırım Doğru SS. Zihin engelli çocuklarda cinsel istismar. Abant İzzet Baysal Üniversitesi Eğitim Fakültesi Dergisi 2006;s.80-91.

42. Bulut S, Karaman HB. Engelli bireylerin cinsel, fiziksel ve duygusal istismarı. Ankara Üniversitesi Eğitim Bilimleri Fakültesi Özel Eğitim Dergisi 2018;19(2):277-301

43. Güleryüz ŞO. Kaynaştırma eğitimine devam eden engelli öğrencilerin akranları ile ilişkilerinde karşılaştıkları sorunların değerlendirilmesi. Selçuk Üniversitesi, Sosyal Bilimler Enstitüsü, Özel Eğitim Anabilim Dall. Yüksek Lisans Tezi. Konya,2009, s.34-41.

44. Durduran Y, Bodur S. Engellilerin engellilikleri dışındaki sağlık sorunları: karşılaştırmalı bir çalışma. Selçuk Tıp Dergisi 2009;25(2):69-77.

45. Yavuz B, Çimen S. Serebral Palsili çocukların öz bakım becerilerini gerçekleştirme düzeyleri ve etkileyen etmenlerin incelenmesi.
Cumhuriyet Üniversitesi Hemşirelik Yüksekokulu Dergisi 2007;11(1):17-26.

46. Türkiye Cumhuriyeti Anayasas1. https://www.mevzuat.gov.tr/MevzuatMetin/1.5.270 9.pdf (Erişim: 07.03.2019)

47. Ulutaşdemir N. Engelli çocukların eğitimi. Fırat Sağlık Hizmetleri Dergisi 2007;2 (5):119-130.

48. T.C. Aile ve Sosyal Politikalar Bakanlığı. Engelli ve Yaşlı hizmetleri Genel Müdürlüğü. Motor Fonksiyonel Problemi Olan Çocuklar Aile Rehberi. Ankara, 2014 ,s.97-122.

49. Dünya Engelliler Vakfı. Engelsiz Şehir Tasarım Raporu. http://www.devturkiye.org/Projeler/Engelsiz-SehirPlanlamasi/Engelsiz-Sehir-Tasarim-Raporu/ (Erişim: 07.03.2019)

50. Çağlar S. Engellilerin erişebilirlik hakkı ve Türkiye'de erişebilirlikleri. Ankara Üniversitesi Hukuk Fakültesi Dergisi 2012;61(2):541-598. 